\title{
From Fresh to Marine Waters: Characterization and Fate of Dissolved Organic Matter in the Lena River Delta Region, Siberia
}

\section{OPEN ACCESS}

Edited by:

Christopher Osburn, North Carolina State University, USA

Reviewed by: Karin M. Björkman, University of Hawaii, USA

John Robert Helms,

Morningside College, USA

*Correspondence:

Rafael Gonçalves-Araujo rafael.goncalves.araujo@awi.de; rafaelgoncalvesaraujo@gmail.com

Specialty section: This article was submitted to Marine Biogeochemistry, a section of the journal

Frontiers in Marine Science

Received: 30 September 2015 Accepted: 23 November 2015 Published: 16 December 2015

Citation:

Gonçalves-Araujo R, Stedmon CA, Heim B, Dubinenkov I, Kraberg A, Moiseev $D$ and Bracher A (2015) From

Fresh to Marine Waters: Characterization and Fate of Dissolved Organic Matter in the Lena River Delta Region, Siberia.

Front. Mar. Sci. 2:108. doi: 10.3389/fmars.2015.00108

\begin{abstract}
Rafael Gonçalves-Araujo ${ }^{1,2 \star}$, Colin A. Stedmon ${ }^{3}$, Birgit Heim ${ }^{4}$, Ivan Dubinenkov ${ }^{2,5}$, Alexandra Kraberg ${ }^{6}$, Denis Moiseev ${ }^{7}$ and Astrid Bracher ${ }^{1,8}$

${ }^{1}$ PHYTOOPTICS Group, Physical Oceanography of Polar Seas, Climate Sciences, Alfred Wegener Institute for Polar and Marine Research, Bremerhaven, Germany, ${ }^{2}$ Faculty of Biology and Chemistry (FB-2), University of Bremen, Bremen, Germany, ${ }^{3}$ Section for Marine Ecology and Oceanography, National Institute for Aquatic Resources, Technical University of Denmark, Charlottenlund, Denmark, ${ }^{4}$ Periglacial Research, Geosciences, Alfred Wegener Institute for Polar and Marine Research, Potsdam, Germany, ${ }^{5}$ Ecological Chemistry, Biosciences, Alfred Wegener Institute for Polar and Marine Research, Bremerhaven, Germany, ${ }^{6}$ Shelf Sea System Ecology, Biosciences, Biologische Anstalt Helgoland, Alfred Wegener Institute for Polar and Marine Research, Helgoland, Germany, ${ }^{7}$ Murmansk Marine Biological Institute of Kola Science Centre, Russian Academy of Sciences, Murmansk, Russia, ${ }^{8}$ Institute of Environmental Physics, University of Bremen, Bremen, Germany
\end{abstract}

Connectivity between the terrestrial and marine environment in the Artic is changing as a result of climate change, influencing both freshwater budgets, and the supply of carbon to the sea. This study characterizes the optical properties of dissolved organic matter (DOM) within the Lena Delta region and evaluates the behavior of DOM across the fresh water-marine gradient. Six fluorescent components (four humic-like; one marine humic-like; one protein-like) were identified by Parallel Factor Analysis (PARAFAC) with a clear dominance of allochthonous humic-like signals. Colored DOM (CDOM) and dissolved organic carbon (DOC) were highly correlated and had their distribution coupled with hydrographical conditions. Higher DOM concentration and degree of humification were associated with the low salinity waters of the Lena River. Values decreased toward the higher salinity Laptev Sea shelf waters. Results demonstrate different responses of DOM mixing in relation to the vertical structure of the water column, as reflecting the hydrographical dynamics in the region. Two mixing curves for DOM were apparent. In surface waters above the pycnocline there was a sharper decrease in DOM concentration in relation to salinity indicating removal. In the bottom water layer the DOM decrease within salinity was less. We propose there is a removal of DOM occurring primarily at the surface layer, which is likely driven by photodegradation and flocculation.

Keywords: DOC, CDOM, FDOM, PARAFAC, optical indices, hydrography, Laptev Sea, Arctic

\section{INTRODUCTION}

Colored or chromophoric dissolved organic matter (CDOM) is the fraction of DOM that absorbs light and it is one of the dominant components influencing the underwater light field in coastal and inner-shelf waters (Siegel et al., 2002; Nelson and Siegel, 2013). CDOM absorbs light in the ultraviolet (UV) and visible wavelength ranges and thus it is able to shield aquatic biota from harmful UV radiation (Arrigo and Brown, 1996) and can be detected by ocean color remote sensing 
(Siegel et al., 2002, 2005). As a result of its UV absorbing properties, CDOM is susceptible to photodegradation, which either induces direct mineralization or produces microbiologically labile low molecular weight compounds, which are subsequently utilized by bacteria (Mopper and Kieber, 2002). Fluorescent DOM (FDOM), which is the part of CDOM able to fluoresce, can be used to trace the supply, mixing, and removal of different fractions of DOM (Yamashita and Tanoue, 2003, 2004; Coble, 2007; Chari et al., 2013; Fukuzaki et al., 2014). With the recent adaptation of the Parallel Factor Analysis (PARAFAC) for analysis of DOM, a more holistic analysis of excitation-emission matrices (EEMs) allows for the differentiation of wider range of underlying DOM components (Stedmon and Bro, 2008). A recent study showed significant associations between molecular groups and PARAFAC-derived DOM components (Stubbins et al., 2014). For instance, the humic-like fluorescent peak A (e.g., Coble, 2007) is associated with high molecular weight compounds with little nitrogen, whereas the humic-like peak C correlated to lignin-derived phenols and the amino acid-like peak $\mathrm{T}$ was associated to low molecular weight and aromatic content compounds, such as hydrolysable amino acids (Stubbins et al., 2014).

By applying the EEMs/PARAFAC technique, the distribution and dynamics of fluorescent DOM have been studied in a wide range of environments varying from lakes (Zhang et al., 2009), estuaries (Stedmon and Markager, 2005; Singh et al., 2010), coastal and shelf (Murphy et al., 2008; Kowalczuk et al., 2010; Para et al., 2010) to pelagic waters (Yamashita et al., 2010; Jørgensen et al., 2011; Kowalczuk et al., 2013). In coastal regions, especially in areas close to river outflows, the riverine input, and its mixing with marine waters are the major factors controlling the distribution and composition of DOM (Stedmon and Markager, 2003; Guo et al., 2007; Alling et al., 2010). In these waters processes such as photobleaching (Opsahl and Benner, 1998; Stubbins et al., 2006; Helms et al., 2008, 2014; Porcal et al., 2013, 2015), sorption to sediments, flocculation (Uher et al., 2001; Shank et al., 2005; Guo et al., 2007; von Wachenfeldt et al., 2008; Asmala et al., 2014), biological uptake (Boyd and Osburn, 2004), biological release (Romera-Castillo et al., 2010), and photo-production of DOM (Helms et al., 2014) can also play a crucial role in controlling the amount, composition, and reactivity of DOM in these environments.

The Arctic Ocean receives considerable input of terrigenous carbon mobilized from high latitude carbon-rich soils and peatlands (Opsahl et al., 1999; Benner et al., 2004). This terrigenous material is supplied by Arctic rivers, which account for more than $10 \%$ of the total riverine and terrestrial organic carbon into the global ocean waters (Opsahl et al., 1999; Benner et al., 2004). Among those rivers, the Lena River (eastern Siberia) accounts for the highest annual DOM discharge into the Arctic Ocean (Raymond et al., 2007; Stedmon et al., 2011), with a peak discharge in June (Amon et al., 2012; Fedorova et al., 2015). It contributes approximately $20 \%$ to the total fresh water discharge into the Arctic Ocean through its delta into the Laptev Sea (Cauwet and Sidorov, 1996). The Lena Delta and the Laptev Sea inner shelf encompass a large, shallow environment characterized by pronounced physical-chemical gradients (Bauch et al., 2009;
Fofonova et al., 2014) and considerable amounts of sediments, dissolved, and particulate organic matter over the water column (Semiletov et al., 2011; Vonk et al., 2012, 2014; Wegner et al., 2013; Heim et al., 2014; Sánchez-García et al., 2014). Eastern Siberia (including the Lena River and its delta) is known to be affected by global warming with a thawing permafrost (Yang et al., 2002; Schuur et al., 2008), which subsequently affects the fresh water discharge, the production of DOM in river catchments and the riverine transport of organic material input into the shelf seas (Frey and McClelland, 2009; Lyon and Destouni, 2010; Semiletov et al., 2012, 2013; Vonk et al., 2012, 2014; Sánchez-García et al., 2014; Fedorova et al., 2015).

The Lena Delta region and Laptev Sea have high DOC concentrations $(>500 \mu \mathrm{M})$ and high CDOM associated with low salinity waters (Alling et al., 2010; Stedmon et al., 2011; Semiletov et al., 2013; Walker et al., 2013; Heim et al., 2014; Dubinenkov et al., 2015a), decreasing toward higher salinities through conservative mixing (Cauwet and Sidorov, 1996; Kattner et al., 1999). This is a characteristic also thought to be shared by other Arctic rivers (Dittmar and Kattner, 2003). However, a recent study has indicated non-conservative mixing of DOC within the Lena Delta region, with average losses of $30-50 \%$ during mixing along the shelf (Alling et al., 2010). These authors also identified additional sources of DOC in the region (such as primary production and coastal erosion), and pointed out photodegradation, flocculation, sedimentation, and microbial activity as possible processes to be responsible for the removal of DOC and humic substances, although currently poorly resolved. Rectifying this is difficult due to not only the remoteness of the location but also because there is a lack of information on the composition, amount, reactivity, and fate of DOM in these waters. Despite the recent techniques applied for DOM analysis and the advances in the knowledge of the dynamics and composition of DOM in some aquatic environments, there is still a considerable lack of information on this important component of the global carbon pool. This is particularly compounded when accounting for the composition and processes modulating the distribution and reactivity of DOM in the Arctic regions. Hence, further studies addressing these issues are essential for a better understanding of the role of DOM in the carbon cycle within the aquatic environments, especially the Arctic Ocean.

In this study DOM characteristics within the Lena Delta region based on fluorescent properties was investigated. The distribution and transformation of the DOM along the fresh water-marine gradient were investigated, using samples collected in September 2013 at the Lena Delta region in the southern Laptev Sea. The findings provide an insight into the fate of Arctic riverine DOM while it is mixed at the shelf with the waters from the Laptev Sea.

\section{MATERIALS AND METHODS}

\section{Sampling}

The Lena Expedition was conducted in late summer 2013 (17 September) on board the Russian R/V "Dalnie Zelentsy" of the Murmansk Marine Biological Institute, in the surrounding 
areas of the Lena River Delta region, Laptev Sea, Siberia. A total of 18 oceanographic stations were occupied and split into four transects (Figure 1A). The hydrographic characteristics of the water column were assessed from vertical profiles acquired with a CTD-profiler SEACAT SBE 19+. Prior to the cruise, temperature, conductivity, and pressure sensors were calibrated at laboratories of the All-Russia D. I. Mendeleyev Scientific and Research Institute for Metrology. Water samples were taken using Niskin bottles at surface and discrete depths chosen based on CTD profiles. The amount of samples per profile and station varied according to the local depth, ranging from two samples at shallow water $(<5 \mathrm{~m})$ and six samples at deeper water stations (e.g., 20-35 m). The full data set used to compose this work is available online in two published datasets (Dubinenkov et al., 2015b; Gonçalves-Araujo et al., 2015a).

\section{Water Column Structure Assessment}

To assess the structure of the water column, vertical profiles of temperature and salinity from the CTD casts were used to obtain potential water density $(\rho)$ profiles. The depth where variations in density were equal or greater than $0.125 \mathrm{~kg} \mathrm{~m}^{-3}$ over a 5 -m depth interval was considered the upper mixed layer depth (UMLD), as adapted from Levitus (1982) and Kara et al. (2000a). The bottom depth was adopted as UMLD for inner shelf stations with vertically mixed profiles. The water column stability parameter (E) was obtained from vertical density variations assessed by the buoyancy or Brunt-Väisälä frequency $\left(N^{2}\right)$, which is defined by $N^{2}=\frac{g}{\rho} \frac{\partial \rho}{\partial z}\left(\operatorname{rad}^{2} \mathrm{~s}^{-2}\right)$ leading to $E=\frac{N^{2}}{g}\left(10^{-8} \mathrm{rad}^{2}\right.$ $\mathrm{m}^{-1}$ ), where $g$ is gravity. The maximum stability immediately below the UMLD was considered to represent the strength of the pycnocline/stratification (Gonçalves-Araujo et al., 2015b; and references therein).

\section{DOC and DOM Sample Processing and Data Analysis}

Water samples for DOC analysis were filtered through $0.7 \mu \mathrm{m}$ $\mathrm{GF} / \mathrm{F}$ filters (Whatman, pre-combusted, $4 \mathrm{~h}, 450^{\circ} \mathrm{C}$ ) and dark stored in a freezer until further analysis in the laboratory. DOC concentrations were measured using high temperature catalytic oxidation (TOC-VCPN, Shimadzu). For external calibration of the instrument potassium hydrogen phthalate (KHP, Merck) was used. All samples were acidified ( $0.1 \mathrm{M} \mathrm{HCl}$ suprapur, Merck) and purged with $\mathrm{O}_{2}$ for $>5 \mathrm{~min}$. Performance of the instrument was recorded by daily analysis of in-lab KHP standard solutions and reference samples (deep sea reference, DSR, Hansell research lab). The instrument blank was $\sim 2 \mu \mathrm{M} \mathrm{C}$ and quality of analysis was monitored continuously based on results of DSR reference samples.

The samples for CDOM analysis were immediately syringefiltered after sampling with Whatman Spartan 13 filters $(0.2 \mu \mathrm{m})$ and then stored in amber glass bottles $(100 \mathrm{~mL})$ and kept cooled in the fridge $\left(4^{\circ} \mathrm{C}\right)$ until further analysis. Before analysis, the samples were mixed and filtered once more through Whatman Spartan 13 syringe filters $(0.2 \mu \mathrm{m})$. Fluorescence EEMs were collected using an Aqualog ${ }^{\circledR}$ fluorescence spectrometer (HORIBA Jobin Yvon, Germany). Freshly produced Milli-Q water was used as reference. Fluorescence intensity was measured across emission wavelengths 220-620 nm (resolution $1.77 \mathrm{~nm}, 4$ pixel) at excitation wavelengths from 240 to $600 \mathrm{~nm}$ with $3 \mathrm{~nm}$ increments, and an integration time of $2 \mathrm{~s}$. The blank-corrected absorbance spectra was converted into Napierian absorption coefficient $(a)$ at each wavelength $(\lambda)$, using the given equation: $a_{\lambda}\left(m^{-1}\right)=\left(2.303 \times A_{\lambda}\right) / L$, where $A_{\lambda}$ is the absorbance at specific wavelength and $L$ is the cuvette path length in meters. The absorption coefficients in the visible $(440 \mathrm{~nm}-$ $\left.\mathrm{a}_{440}\right)$ and UV $\left(350 \mathrm{~nm}-\mathrm{a}_{350}\right)$ bands are generally adopted as indicators of CDOM magnitude. Although many studies have presented their results using the absorption coefficient at $440 \mathrm{~nm}$ $\left(\mathrm{a}_{440}\right)$ due to its application to ocean color remote sensing (e.g., Siegel et al., 2005; Heim et al., 2014), in this study we determined the absorption coefficients in both visible $\left(\mathrm{a}_{440}\right)$ and UV $\left(\mathrm{a}_{350}\right)$ ranges. Nevertheless, we focus our results and discussions on the $\mathrm{a}_{350}$ coefficient because of its correlations to DOC and lignin concentrations and to permit comparison
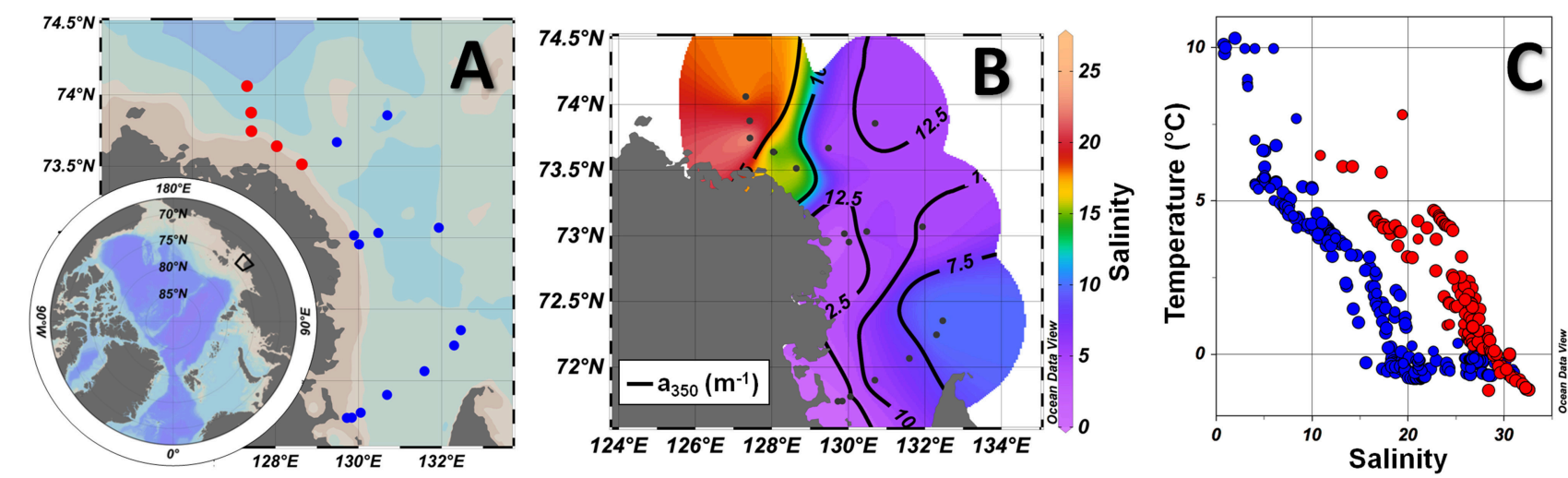

FIGURE 1 | (A) View of the Northern Hemisphere with the coverage of the sampled area in the black box, which is zoomed in highlighting the Lena delta region and southern Laptev Sea, as well as oceanographic stations and transects occupied during the Lena Expedition 2013. (B) Surface distribution of salinity (colorbar) and $\mathrm{a}_{350}\left(\mathrm{~m}^{-1}\right.$; solid black lines). (C) T-S diagram for all the stations, with the plume-influenced and marine-influenced stations displayed in blue and red, respectively. Marine-influenced stations (surface salinity >10) are displayed in red in (A) and in the transects. Produced with Ocean Data View (Schlitzer, 2015). 
with earlier results (Spencer et al., 2009; Stedmon et al., 2011; Walker et al., 2013). The raw EEMs acquired with Aqualog ${ }^{\circledR}$ were corrected for inner-filter effects and for the Raman and Rayleigh scattering (Murphy et al., 2013). The different fluorescent components of DOM were isolated from combined signal by PARAFAC modeling using the "drEEM Toolbox" and following the recommendation of Murphy et al. (2013). The DOM components derived from PARAFAC modeling were compared with PARAFAC components from other studies through the OpenFluor database (Murphy et al., 2014). The complete absorption and emission spectra of the fluorescent components derived from PARAFAC are available on the OpenFluor database after publication (http://www.openfluor. org). We have estimated the hypothetical conservative mixing of DOM (i.e., $\mathrm{a}_{350}$, DOC, and fluorescence intensity of each of the PARAFAC components) by considering the average of two values of the respective parameter at the highest and at the lowest salinity extremities, respectively, as the end points of the conservative line.

\section{DOM Modification Indices, Statistical Analyses, and Graphical Tools}

Besides the determination of the magnitude and characterization of DOM components, the optical characteristics of CDOM and FDOM can also be used to assess the origin and degree of transformation of DOM through the calculation of optical indices. By applying an exponential function to the $275-295 \mathrm{~nm}$ spectral range it is possible to derive the spectral slope of absorption spectra $\left(\mathrm{S}_{\mathrm{CDOM}}\right.$, in $\left.\mu \mathrm{m}^{-1}\right)$ that varies in relation to the source of CDOM. It has also been shown to be inversely correlated with the molecular weight of DOM and can be related to photobleaching (Helms et al., 2008; Fichot and Benner, 2012; Fichot et al., 2013). The specific UV absorbance (SUVA) is used as a proxy for the degree of aromaticity in CDOM samples (Weishaar et al., 2003) and it is defined by SUVA $=A_{254} /[D O C]$, where $A_{254}$ is the absorbance at $254 \mathrm{~nm}$ and the concentration of DOC, [DOC], is measured in $\mathrm{mg} \mathrm{CL}^{-1}$. Due to the high absorption of aromatic compounds in the UV-visible, higher SUVA values indicate higher aromaticity from allochthonous input (e.g., humic compounds), while lower SUVA values are associated to more autochthonous or modified terrestrial CDOM with lower aromaticity (Weishaar et al., 2003).

Two optical indices, that take FDOM into account, were also used to investigate both the degree of humification and biological degradation of the DOM. The humification index (HIX) estimates the degree of maturation of DOM (Zsolnay et al., 1999; Zsolnay, 2003), considering that humification is associated with an increase in the $\mathrm{C} / \mathrm{H}$ ratio (Stevenson, 1982) and is thus reflected in emissions at longer wavelengths (Senesi et al., 1991). The HIX index is the ratio of the areas of two spectral wavelength regions in the emission spectra for an excitation at $254 \mathrm{~nm}$ and it is obtained as: $H I X=H / L$, where $H$ is the area between 435 and $480 \mathrm{~nm}$ in the emission spectra and $L$ is the area in the emission spectra between 300 and $345 \mathrm{~nm}$ (Zsolnay et al., 1999). An increase in the degree of aromaticity (humification) leads to a red shift in the emission spectrum, which will be associated with higher HIX values. The biological/autochthonous index (BIX) is used to assess the biological modification of DOM based on UV fluorescence. The BIX index is obtained by calculating the ratio of the emission at 380 and $430 \mathrm{~nm}$, excited at $310 \mathrm{~nm}$ : BIX = $I_{E m 380} / I_{E m 430}$ (Huguet et al., 2009). High BIX values correspond to autochthonous origin of DOM, i.e., freshly released DOM, whereas low BIX values indicate allochthonous DOM (Huguet et al., 2009).

The relationships between all pairs of variables were investigated using Spearman correlation coefficients. To compare the variables among themselves or among different groups of samples, Kruskal-Wallis $\mathrm{H}$ tests were applied, after performing normality tests. Furthermore, the relationship between each pair of variables was determined based on linear regressions.

\section{RESULTS}

\section{Hydrography and Water Column Structure}

Pronounced environmental variability was observed within the studied region, with sampling varying from fresh to marine waters, as demonstrated by the noticeable hydrographical gradients in the T-S diagram (Figure 1C). Salinity varied between 0.90 and 32.63, with the lowest values associated with fresh water input from the Lena River and plume (Figures 1B,C). Temperature ranged from -1.2 to $10.3^{\circ} \mathrm{C}$, with higher values related to the warmer and fresher Lena river plume and the lowest values attributed to the presence of the colder and saltier Laptev Sea shelf waters. In addition, a strong horizontal frontal zone was found within the NW portion of the study area, with the isohaline of 10 depicting the surface limit between two hydrographic provinces observed: the sites under direct influence of fresher Lena River plume and the sites under influence of the saltier waters from the Laptev Sea shelf (Figures 1A,B), hereafter named as plume- and marine-influenced stations. Note that, although named marine-influenced stations, those sites were still under influence of the continental fresh water input, however less than the plume-influenced ones, given the still low salinity observed at surface (varying from 13.21 to 25.60; Figure 1B).

A low salinity surface layer generated by the influence of the fresh waters from the Lena River was observed along the entire sampled area (Figure 1). The occupation of the surface layer by the river plume leads to the establishment of an upper mixed layer of $\sim 10 \mathrm{~m}$ and a pronounced vertical gradient of density. Nevertheless, a few shallower stations ( $<5 \mathrm{~m}$ deep) close to the main outflows of the Lena River (Bykovskaya and Trofimovskaya) were characterized by vertically mixed profiles with very low salinity $(<3)$ waters from the Lena plume. The stability parameter $(E)$ was obtained for all the stations where a vertical stratification was observed. The strength of the pycnocline was inversely related to the surface salinity $\left(r^{2}=\right.$ $0.82 ; p<0.01)$. Thus, the plume-influenced stations exhibited a greater stratification in comparison to the marine-influenced ones, with averaged $E$-values of about $7.01 \pm 2.84 \times 10^{-8}, 4.32 \pm$ $1.79 \times 10^{-8}$, and $3.98 \pm 1.80 \times 10^{-8} \mathrm{rad}^{2} \mathrm{~m}^{-1}$ for stations located at the inner-plume (surface salinity $<5$ ), outer-plume $(5<$ surface salinity $<10)$ and marine-influenced stations (surface salinity $>10$ ), respectively). 


\section{CDOM and DOC Spatial Variability}

CDOM displayed a distribution tightly coupled with salinity (see Figures 1B, 2). a 350 ranged from 0.9 to $15.7 \mathrm{~m}^{-1}$ (Figure 2) and showed a significant negative correlation with salinity $\left[\mathrm{a}_{350}=-\right.$ 0.377 (salinity) $\left.+12.774 ; r^{2}=0.96 ; p<0.0001\right]$. The highest $\mathrm{a}_{350}$ values were observed within the fresher waters under the influence of the Lena plume with a decrease in $\mathrm{a}_{350}$ toward the saltier waters from the Laptev Sea. DOC ranged from 110 to $732 \mu \mathrm{M}$ and was highly correlated to $\mathrm{a}_{350}\left[\mathrm{DOC}=38.529\left(\mathrm{a}_{350}\right)+\right.$ 106.889; $r^{2}=0.99 ; p<0.0001$ ], exhibiting a very similar behavior as CDOM across the salinity gradient [DOC $=-$ 14.878(salinity) + 605.236; $r^{2}=0.96 ; p<0.0001$ ] (Figure 2). Additionally, $\mathrm{a}_{440}$ varied between 0.12 and $2.97 \mathrm{~m}^{-1}$ and it was significantly highly correlated to $\mathrm{a}_{350}\left[\mathrm{a}_{350}=5.188\left(\mathrm{a}_{440}\right)+0.361\right.$; $\left.r^{2}=0.99 ; p<0.0001\right]$ and DOC $\left[\mathrm{DOC}=199.057\left(\mathrm{a}_{440}\right)+\right.$ 121.760; $\left.r^{2}=0.98 ; p<0.0001\right]$.

When taking into account the relationship between DOM and salinity for each of the hydrographic provinces separately, some features/patterns become clear (Figures 2, 3): a higher DOM amount is associated to the plume-influenced sites; a steeper curve is exhibited by samples above the pycnocline in relation to the samples below it; and there is low variability in DOM along the pycnocline itself. In addition, the $\mathrm{a}_{350}$ vs. salinity curve above the pycnocline displayed by the plume-influenced sites was even steeper then the same curve for the marineinfluenced sites (Figure 3). Overall, a non-conservative behavior is observed in the low salinity, surface layer (given the deviation in relation to the hypothetical conservative mixing line) with an indication of removal of DOM (deviating up to 56\% from the hypothetical conservative mixing line). That deviation decreases at the underlying layer, suggesting a conservative mixing of DOM in those waters (see Figures 2, 3).

\section{FDOM Components by PARAFAC}

Six fluorescent components (C1-C6) were identified by the PARAFAC model (Figure 4). Four components had broad emission and excitation spectra, with emission maxima at visible wavelengths typical of humic-like material (C1, C2, C4, and C5). C3 and C6 had comparably narrow UVA emission maxima. The fluorescence intensity of the components differed greatly, with $\mathrm{C} 1$ having the greatest values (reaching up to $2.08 \mathrm{~nm}^{-1}$ ) and C6 the lowest (up to $0.18 \mathrm{~nm}^{-1}$; Figure 4). The humic-like components $\mathrm{C} 1$ and $\mathrm{C} 2$ were the dominant fluorescent signals, accounting for more than 50\% of total FDOM in all the samples. The humic-like contribution to total FDOM reached up to $86 \%$ at low salinity (see colorbar in Figure 5), and was inversely related to salinity $(p<0.0001)$. C1, C2, C3, and C4 presented a similar scattered pattern in relation to salinity. A steeper curve at low salinity $(<10)$ suggests removal in that layer, whereas a less steep curve fit at high salinity $(>10)$ indicates the presence of a conservative mixing (Figure 4, right panel). Although being likewise inversely correlated with salinity, C5 and C6 presented distinct patterns
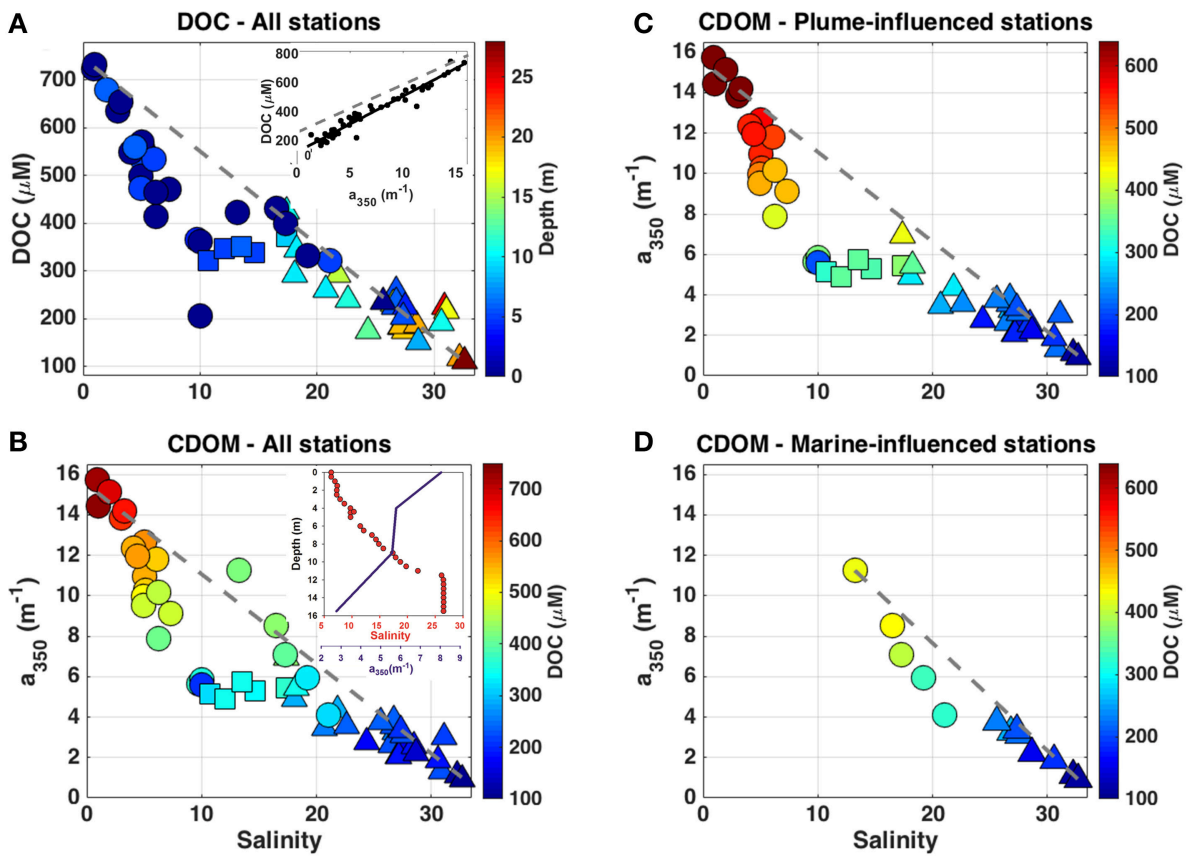

FIGURE 2 | (A) DOC ( $\mu$ M) against salinity and depth for all the samples related to this study ( $m$; colorbar). (B) $a_{350}\left(m^{-1}\right)$ against salinity and DOC for the entire dataset used in this study ( $\mu \mathrm{M}$; colorbar), which was split into two subsets regard to the hydrographical conditions: the plume-influenced stations (C) and the marine-influenced stations (D) that are plotted against salinity and DOC ( $\mu \mathrm{M}$; colorbar). In all the plots, samples above the pycnocline are displayed as circles, samples at the pycnocline as squares, and samples below the pycnocline are displayed as triangles. Gray dashed-lines indicate the hypothetical conservative mixing line between DOM (or DOC) and salinity. Inset graph in (A) shows the relationship between $\mathrm{a}_{350}\left(\mathrm{~m}^{-1}\right)$ and DOC ( $\mu$ M) and the dashed line shows the fit exhibited for the coastal Canadian Arctic (Walker et al., 2009). Inset graph in (B) exhibits vertical distribution of salinity (red dots) and $\mathrm{a}_{350}$ ( $\mathrm{m}^{-1}$; blue line) for one typical plume-influenced station. 

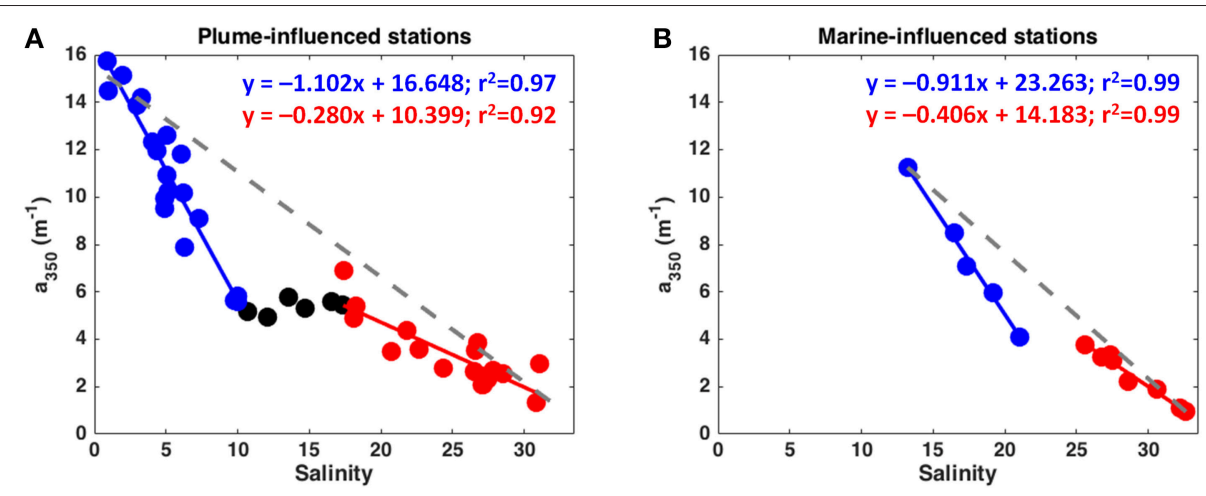

FIGURE 3 | $\mathbf{a}_{\mathbf{3} 50}$ against salinity plot for the Plume-influenced (A) and Marine-influenced (B) stations. Samples above the pycnocline are displayed in blue whereas the ones below it are presented in red. Samples located at the pycnocline are displayed in black. All the fits presented in this figure are significant $(p<0.0001)$. Gray dashed-lines indicate the hypothetical conservative mixing line between DOM and salinity for each of the plots.

when compared to the other components (Figure 4). Both components exhibited a non-conservative mixing, however with indication of release/production during the transit from the river to the outer shelf (Figure 4, right panel).

\section{Optical Indices of DOM Modification}

Different optical indices including $\mathrm{S}_{\mathrm{CDOM}}$, SUVA, HIX, and BIX indices (in Figure 5 shown in relation to salinity), as well as the slope ratio ( $\mathrm{S}_{\text {Ratio }}$; Helms et al., 2008) and the fluorescence index (FI; McKnight et al., 2001; not shown) were evaluated within all samples. All indices, except $S_{\text {Ratio }}(p>0.05)$, were significantly correlated with salinity, $\mathrm{a}_{350}$, DOC and FDOM, and by that also to each other $(p<0.0001)$. Although it was not significantly correlated to salinity $(p>0.05)$, the $S_{\text {Ratio indicated a dominance of terrigenous signal over the }}$ entire sample area, given that most of the samples ( 93\%) presented $S_{\text {Ratio }}$ values below 1 (Figure 5E). In addition, the lack of significance between $S_{\text {ratio }}$ and salinity might be due to an increase in the signal-to-noise ratio for the absorbance spectra at wavelengths longer than $350 \mathrm{~nm}$ observed in samples at higher salinity that, in turn, presented the greatest variability in $\mathrm{S}_{\text {Ratio }}$ values. $\mathrm{S}_{\mathrm{CDOM}}$ ranged from 15.5 to $21.4 \mu \mathrm{m}^{-1}$ and was directly related to salinity (Figure 5A), suggesting a decrease in the molecular weight with increased salinity (Helms et al., 2008). The values observed for the SUVA index were high, ranging from 1.33 to $4.80 \mathrm{~m}^{2} \mathrm{~g}^{-1}$, and was inversely related to salinity $(p<$ 0.0001 ), evidencing a decrease in the aromaticity of the molecules toward high salinity (Figure 5B). The HIX index values ranged from 3.4 to 16.6 , and the BIX index values were lower than 0.73 (Figures 5C,D, respectively), indicating a high degree of humification and low autochthonous contribution within our sample set, respectively. Moreover, HIX and BIX showed a decrease (increase) in the degree of humification (DOM from biological activity) with increase in salinity, given the significant relationship ( $p<0.0001$ ) displayed by those indices and salinity (Figures 5C,D). FI presented values below 1.3 and was inversely related $(p<0.0001)$ to salinity (not shown), indicating a consistent predominance of terrestrial sources of DOM to the region.

\section{DISCUSSION}

\section{Characterization and Transformation of DOM}

The results characterize the DOM composition (here using the EEM/PAFARAC approach and optical indices of DOM modification) along the fresh water-marine gradient within the Lena delta region and Laptev Sea. Four of the six fluorescent components identified by PARAFAC analysis, three humic-like (C1, C2, and C5) and one protein-like (C6; see Figure 4-center), were already reported in the Lena River and in other large Arctic rivers (Walker et al., 2013). In addition, a recent study reported the presence of three of those components (C1, C2, and C6) in the Amerasian basin (Guéguen et al., 2015), which seem to be common components of the Arctic DOM pool. Although, our sampling was carried out during a period of mid discharge flow (Stedmon et al., 2011), C1 and C2 presented similar fluorescence intensities to the average observed for the Lena River during the discharge peak $\left(\sim 1.6\right.$ and $0.9 \mathrm{~nm}^{-1}$, respectively; Walker et al., 2013). C5 and C6, on the other hand, presented intensities close to the average observed in the Lena during the mid discharge flow (see Figure 4-right column; Walker et al., 2013). Our results demonstrate that the FDOM composition in the Lena Delta region was mainly characterized by the dominance of riverine humic-like compounds. This is evidenced by the high contribution of the allochthonous humic-like components with fluorescence in the visible range (C1, C2, C4, and C5) observed in relation to the total FDOM (Figure 4), as well as by the optical indices of DOM modification (Figure 5). A recent study has identified PARAFAC components similar to our humiclike $\mathrm{C} 1$ (also referred in the literature as the classical peak $\mathrm{C}$ ) and $\mathrm{C} 4$, which presented strong correlation to lignin phenol concentrations (Yamashita et al., 2015). Dominance of humiclike compounds has been already reported in the Lena Delta in late summer 1995, when high concentrations of lignin, and high contribution of terrigenous DOC (about $60 \%$ of total DOC) were observed (Kattner et al., 1999). The humic-like component 1 is a dominant component of the FDOM signal not only in the Lena River and Delta, but it has also been found to be 

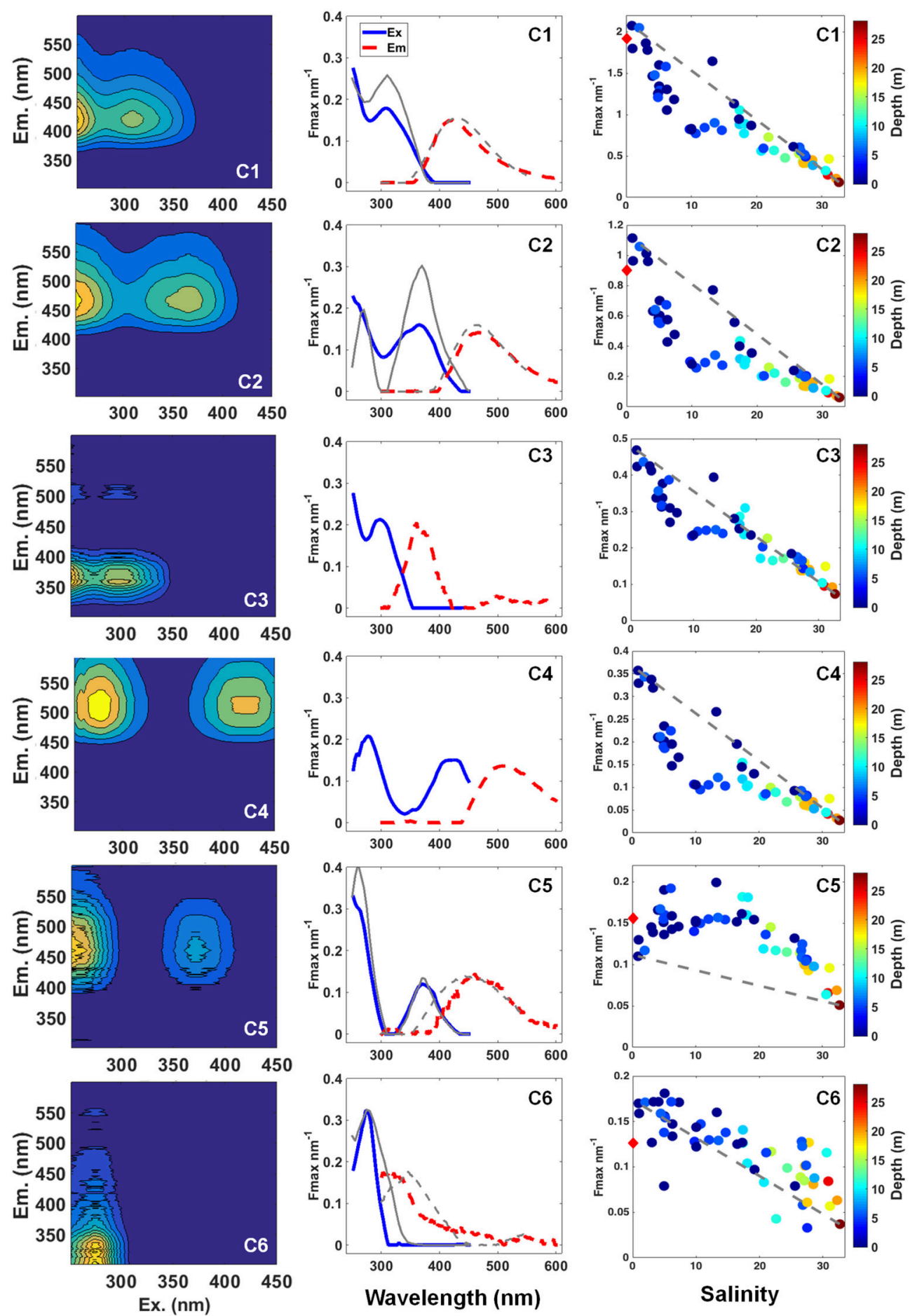

FIGURE 4 | Three-dimensional fluorescence landscapes (left), the excitation (solid line) and emission (dashed line) spectra (center), and $F_{m a x}\left(\mathrm{~nm}^{-1}\right.$ ) against salinity and depth ( $\mathrm{m}$; right) for each of the six fluorescent components identified by PARAFAC model for all the samples. Gray lines displayed in components spectra graphs (center) show the spectra for components previously found in the major Arctic Rivers (Walker et al., 2013). Gray dashed-lines in $F_{\text {max }}$ against salinity plots (right) indicate the hypothetical conservative mixing line between each of the components and salinity. Red diamonds in $y$-axis indicate averaged Fmax values for similar components found in the Lena River during periods of peak discharge (for C1 and C2) and mid flow (for C5 and C6; Walker et al., 2013). 

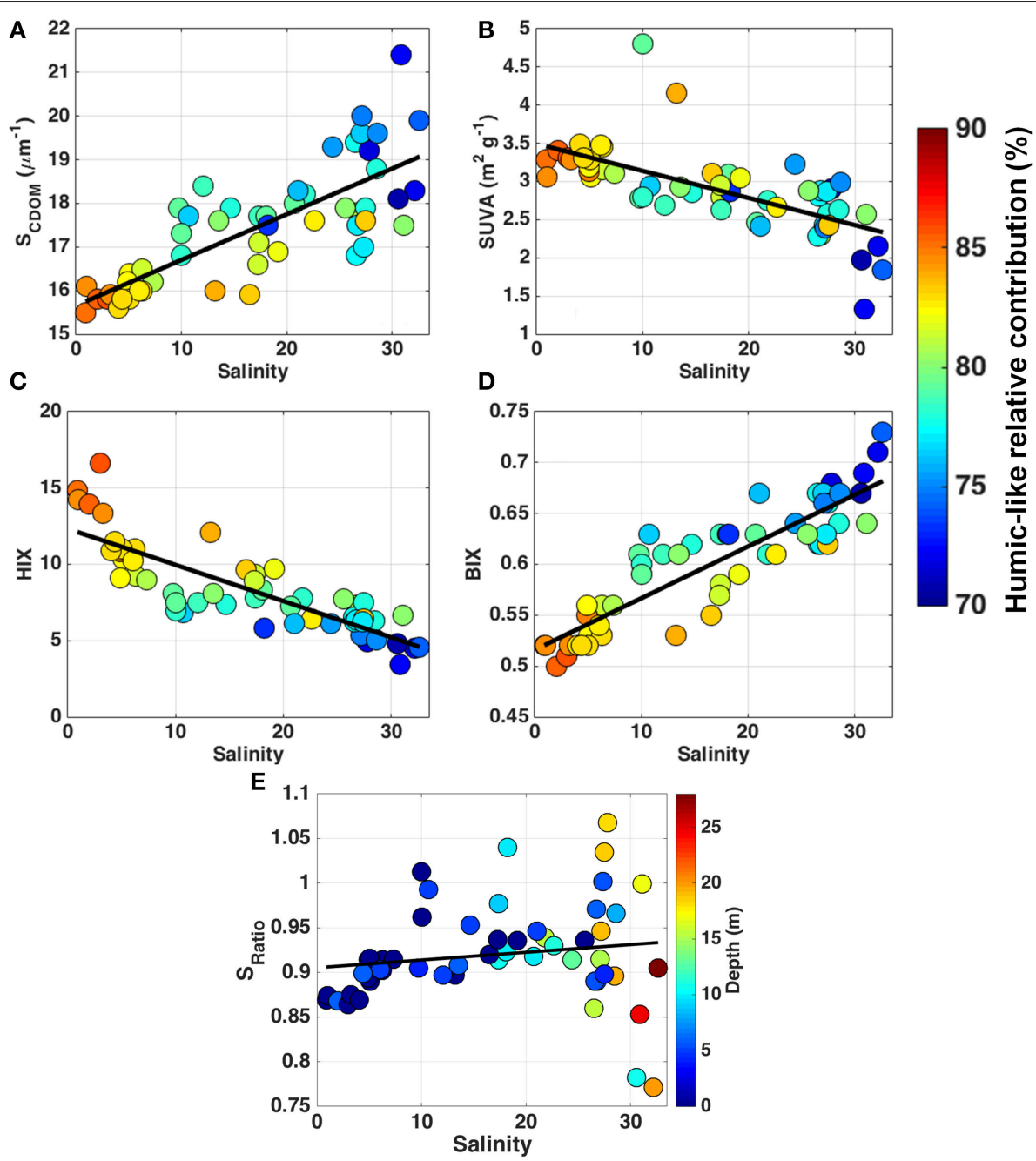

FIGURE 5 | The relationship between the optical indices of DOM modification and salinity for all the samples: $S_{C D O M}\left(\mu m^{-1}\right)(A) ; S$ VVA ( $\left.m^{2} g^{-1}\right)(B)$; HIX (C); BIX (D); Slope ratio (E). Colorbar indicates the relative contribution (\%) of the humic-like signal $(C 1+C 2+C 4+C 5)$ to the total FDOM (A-D) and depth (m; E). Black lines indicate the regression lines between each parameter and salinity.

dominant in other Arctic rivers such as Mackenzie, Kolyma, Ob, and Yenisei (Walker et al., 2009, 2013), in the Amerasian basin (Guéguen et al., 2015) and in shelf waters in the North Atlantic (Kowalczuk et al., 2009; Yamashita et al., 2013). In accordance to the results obtained with the EEM/PARAFAC approach, the optical indices of DOM modification have also pointed to a dominance of humic-like compounds within the samples (see Figure 5).

Despite the dominance of allochthonous humic-like components over the entire sampled area, autochthonous components (such as the marine-humic like C3 and the proteinlike C6) have their relative contribution (to total FDOM signal) enhanced toward high salinity (see colorbar in Figure 5). Increased relative contribution of C6 was also observed during the base flow of the Lena River, when the terrestrial input is reduced (Walker et al., 2013). In addition, the component C6, also referred in other studies as tryptophan-like, seems to be a useful indicator of bioavailability of DOM, given the strong correlation showed by it and total dissolved amino acids concentrations (Yamashita et al., 2015). The increase observed in the relative contribution of autochthonous compounds toward the high salinity waters of the Laptev Sea shelf region was also evident when observing the ranges presented by the optical indices of DOM modification (see Figure 5). Furthermore, those indices can provide more information on the transformation of the DOM during the transit from the river to the outer shelf. The use of optical indices has been successfully applied to assess the transformation of DOM along wide salinity ranges in some estuary regions worldwide (Benner and Opsahl, 2001; Helms et al., 2008, 2014; Huguet et al., 2009; Asmala et al., 2014). The values obtained for the optical indices at low salinity in our study are in agreement with previous studies conducted in the Lena River. For instance, those studies have reported $\mathrm{S}_{\mathrm{CDOM}}$, SUVA, and BIX values around $16 \mu \mathrm{m}^{-1}, 2.8 \mathrm{~m}^{2} \mathrm{~g}^{-1}$ and 0.52 , 
respectively (Stedmon et al., 2011; Walker et al., 2013). All the optical indices taken into account in this study demonstrated that the DOM in the Lena delta region experiences an evident transformation along the riverine-marine transition. This is supported by the reduction on the molecular weight, aromaticity and humification degree of DOM observed toward high salinity, with the more photochemically reactive compounds associated to the surface (with lower salinity) layer and components with more refractory character being associated to the high salinityLaptev Sea shelf waters (Figure 5). The possible mechanisms driving the observed transformation in DOM are discussed in the following section.

\section{Dynamics and Fate of DOM in the Lena Delta Region}

The hydrographic observations during our campaign revealed strong gradients, with noticeable northward propagation of the Lena River plume along the study region. This generated a shallow, low salinity surface mixed layer with strong stratification, which separates the surface layer from the underlying high salinity layer with Laptev Sea shelf water (see Figure 1). The propagation of the plume along the Laptev Sea shelf has also induced the establishment of a strong frontal system in the NW part of our study area (see Figure 1). Such hydrographic characteristics were previously described as offshore wind conditions, when the predominant winds from the continent drive the offshore propagation of the Lena waters generating a strong stratification and a frontal system NW of the Lena Delta region (Bauch et al., 2009; Wegner et al., 2013). Thus, we have identified the presence of two hydrographic provinces within the sampled area: the plume- and marine-influenced sites (see Figure 1).

The noticeable variability in hydrographic conditions due to the dynamics between fresh water input from the Lena River and the Laptev Sea shelf waters were also reflected in the striking differences of the amount and composition of DOM (Figures 2, 3). The association of the highest DOM concentrations with the low salinity waters of the Lena outflow decreasing toward the high salinity Laptev Sea shelf waters (see Figure 2) re-emphasizes the importance of the Lena River as a major source of DOM to the Laptev Sea. Such inverse relationship has previously been indicated for this region (Cauwet and Sidorov, 1996; Kattner et al., 1999; Alling et al., 2010; Semiletov et al., 2013; Heim et al., 2014) and it is the case for many other estuary regions (Benner and Opsahl, 2001; Guo et al., 2007; Huguet et al., 2009). Both CDOM and DOC were highly correlated, displaying a similar relationship as found for the coastal Canadian Arctic (Walker et al., 2009; see Figure 2), although with a higher $\mathrm{a}_{350}$ relative to DOC in the Lena delta waters. The presented values are comparable to other studies previously conducted in this region, with $\mathrm{a}_{350}\left(\mathrm{a}_{440}\right)$ values of about $15 \mathrm{~m}^{-1}\left(2.9 \mathrm{~m}^{-1}\right)$ at low salinity and DOC concentrations ranging from $500-700$ to $100 \mu \mathrm{M}$ at low and high salinity, respectively (Alling et al., 2010; Stedmon et al., 2011; Semiletov et al., 2013; Walker et al., 2013; Heim et al., 2014; Dubinenkov et al., 2015a).
Our results show a coupled relationship between DOM and the two hydrographic provinces identified in this work. Plumeinfluenced stations presented higher DOM concentrations at surface as compared to marine-influenced stations $(p<0.001$; see Figure 1). Despite these differences within the surface layers, both hydrographic provinces exhibited similar patterns regarding the relationship between DOM and salinity. Distinct DOM mixing patterns (in relation to salinity) were observed for samples above and below the pycnocline, i.e., the low and high salinity layers, respectively (Figure 6). The mixing curves derived from samples above the pycnocline exhibited higher slope than the ones below it (see Figures 2, 3, 6). The same pattern is observed when looking at the results from an expedition conducted at the Lena Delta region in September 2005 (see Figure 9 in Semiletov et al., 2013); however, the possible causes of this pattern were not addressed in that study. We suggest that such an increase in the slope of the relationship can be interpreted as a non-conservative decrease in DOM concentration along with the surface layer. This DOM removal in the surface (lower salinity) layer occurred despite the short residence time (of about 2 months) the Lena River plume waters in the Laptev Sea (Alling et al., 2010). Release/production of the components C5 and C6 was observed along the entire riverine-marine transition (see Figure 4, right panel). The autochthonous protein-like C6 is known to be released by microbial metabolism (RomeraCastillo et al., 2010; Fukuzaki et al., 2014) and its release in our sampling area can be related to the microbial community presented within the region. On the other hand, the humic-like C5 could have had its release associated with photoproduction, given that some humic-like components, such as alkyl, have been shown to be produced via that process (Helms et al., 2014). Although the components C5 and C6 presented indication of release/production along the riverine-marine transition, the contribution of those components to the total fluorescence signal was small (less than 20\%). Thus, the overall DOM mixing curve mirrored the curves displayed by C1-C4 (accounting for more than $80 \%$ of the total FDOM signal), with a removal of DOM at low salinities and a conservative mixing behavior related to the saltier Laptev Sea shelf waters. Non-conservative mixing characterized by removal at low salinities seems to be a characteristic shared by other estuarine regions in the Baltic Sea (Kowalczuk et al., 2010; Asmala et al., 2014).

Given the strong stratification observed within the sampled area, we assume that exchanges between surface and underneath layer are limited (Kara et al., 2000b) compared to well-mixed conditions. As a result, the humic-like-dominated, highly photoreactive DOM (Helms et al., 2014; Timko et al., 2015) is exposed longer to photochemical degradation (Fichot and Miller, 2010). This process is evidenced by the relationship between $S_{\text {Ratio }}$ and salinity (Figure $5 E$ ), with high $S_{\text {Ratio values }}(>0.95)$ observed in intermediate salinity (10-20). Furthermore, the influence of particulate matter and sediments in coastal and shelf environments has to be taken into account given their influence on DOM removal through the process of sorption and flocculation (Uher et al., 2001; Shank et al., 2005; Guo et al., 2007; Asmala et al., 2014). The flocculation process, in turn, can be increased either due to the presence of the salt in the 


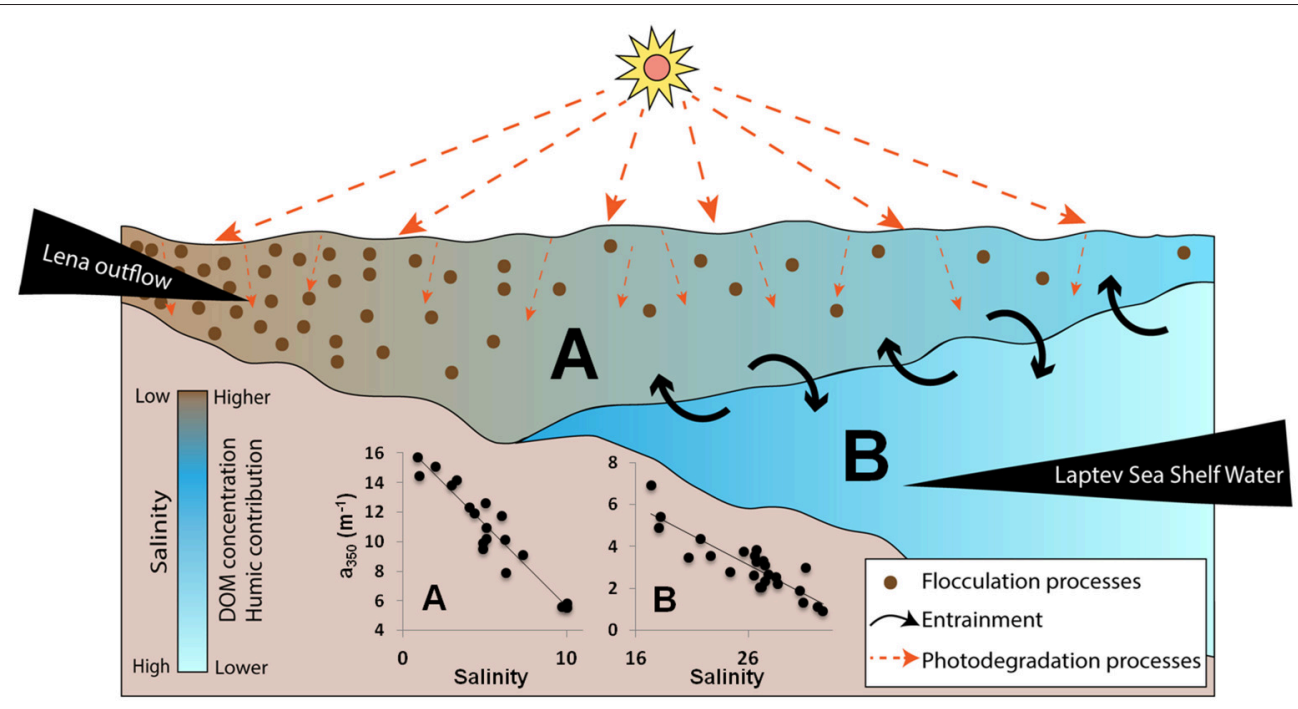

FIGURE 6 | Schematic diagram showing the complex interactions occurring in the Laptev Sea continental shelf, close to the Lena River delta region. The vertical distribution of the two water masses found within the region (Lena River plume and Laptev Sea Shelf waters) is presented. A strong gradient between the two water masses with limited exchanges between them is depicted. Salinity, DOM concentration and the humic-like contribution are shown in the colorbar. The main removal processes within the surface layer (photodegradation and flocculation) are demonstrated by the symbols presented in the inset legend. Inset graphs show the $\operatorname{DOM}\left(\mathrm{a}_{350} ; \mathrm{m}^{-1}\right)$ against salinity plots for the Lena plume (A) and Laptev Sea shelf Waters (B).

marine water (Asmala et al., 2014, and references therein) and to the exposition to high light intensities that, together with photochemical processes, can synergistically enhance the DOM removal from the dissolved phase (von Wachenfeldt et al., 2008; Porcal et al., 2013, 2015). A sharp decrease in POC concentrations at low salinity has been reported in the Lena delta region and was attributed to sinking of particles (Cauwet and Sidorov, 1996). We speculate that the main drivers on the apparent removal of highly humic content DOM observed within the surface layer are the photodegradation and flocculation, given the high susceptibility of those aromatic carbons to those processes (von Wachenfeldt et al., 2008; Porcal et al., 2013, 2015; Asmala et al., 2014; Helms et al., 2014). Those processes have also been indicated to modulate the non-conservative mixing behavior in other estuaries such as the Mississippi delta (Benner and Opsahl, 2001). Our findings from late summer 2013 corroborate the indication of DOM removal within the region as observed in late summer 2008 (Alling et al., 2010); however, with a more refined spatial coverage, we have demonstrated that the removal of DOM occurs mostly in the low salinity surface layer (Figure 6).

Considering that the impact of temperature increases to the Arctic and Siberian environments, an increase in permafrost thawing rates, changes in the freshwater budget, catchment vegetation and hydrology, and subsequent DOM discharge into the Arctic Ocean are expected (Peterson et al., 2002; McClelland et al., 2004; Frey and McClelland, 2009). As a consequence, changes in concentration and composition of DOM are expected, given the release of ancient DOM trapped in the permafrost layer due to its thaw (Aiken et al., 2014; O'Donnell et al., 2014), and given the variability of DOM composition in response to variations in river discharge (Walker et al., 2013). Subsequently, with an enhanced input of DOM (especially CDOM) into the Arctic Ocean, changes in the radiant heating in the upper meters of the ocean as well as a possible increase in the sea-ice melt rates might be foreseen (Granskog et al., 2015). Furthermore, the characteristics of DOM have been shown to be a powerful proxy for tracing organic substances with permafrost origin (Aiken et al., 2014; O’Donnell et al., 2014; Dubinenkov et al., 2015a). Moreover, long-term studies concerning the quantification, composition and dynamics of DOM, from fresh to marine waters in the main rivers flowing into the Arctic Ocean, are needed to improve the understanding of DOM dynamics, its role in the carbon cycle pathways. Thus, a better comprehension of DOM composition and its fate, as presented in this study, can be used as baseline for further monitoring of the sources, biogeochemical implications and export of riverine DOM with regard to climate change effects in northern Siberian environments and Arctic Ocean.

\section{SUMMARY}

This study brings new insights on the composition, transformation and fate of DOM in the Lena Delta region. DOM composition evaluated through PARAFAC modeling showed dominance of strong humic-like signal over the entire sampled area. We have demonstrated that the dynamics between the Lena River outflow and Laptev Sea shelf waters is the main driver controlling the hydrographical conditions and, consequently, the DOM behavior within the region. Higher DOM concentrations (also with higher humic-like content) were associated to the low salinity waters of the Lena River that showed to be the main DOM source for the region. The concentration of 
DOM, as well as its humic-like content and reactivity, decreased along the fresh water-marine gradient toward high salinity. Although being limited by sampling within a synoptic scale, we have identified different mixing behaviors of DOM coupled with the dynamics between the Lena River plume and the Laptev Sea shelf waters, which were expressed through the vertical structure of the water column: a sharper decrease in DOM concentration in relation to salinity is observed in waters above the pycnocline, under influence of the low salinity waters from the continental runoff. This indicates that different processes modulating the distribution, composition, and reactivity of DOM occur within the two layers and that there is evidence of removal of DOM in the surface mixed layer. Thus, we suggest photodegradation and flocculation as the main drivers on modulating the removal of highly humified DOM within the surface layer of the Lena Delta region.

\section{ACKNOWLEDGMENTS}

The authors acknowledge the Captain and the crew of the $\mathrm{R} / \mathrm{V}$ "Dalnie Zelentsy" and the researchers E. Druzhkova and

\section{REFERENCES}

Aiken, G. R., Sepncer, R. G. M., Striegl, R. G., Schuster, P. F., and Raymond, P. A. (2014). Influences of glacier melt and permafrost thaw on the age of dissolved organic carbon in the Yukon River basin. Global Biogeochem. Cycles 28, 525-537. doi: 10.1002/2013GB004764

Alling, V., Sanchez-Garcia, L., Porcelli, D., Pugach, S., Vonk, J. E., van Dongen, B., et al. (2010). Nonconservative behavior of dissolved organic carbon across the Laptev and East Siberian seas. Global Biogeochem. Cycles 24, GB4033. doi: 10.1029/2010GB003834

Amon, R. M. V., Rinehart, A. J., Duan, S., Louchouarn, P., Prokushkin, A., Guggenberger, G., et al. (2012). Dissolved organic matter sources in large Arctic rivers. Geochim. Cosmochim. Acta 94, 217-237. doi: 10.1016/j.gca.2012.07.015

Arrigo, K. R., and Brown, C. W. (1996). Impact of chromophoric dissolved organic matter on UV inhibition of primary productivity in the Sea. Mar. Ecol. Prog. Ser. 140, 207-216. doi: 10.3354/meps140207

Asmala, E., Bowers, D. G., Autio, R., Kaartokallio, H., and Thomas, D. N. (2014). Qualitative changes of riverine dissolved organic matter at low salinities due to flocculation. J. Geophys. Res. Biogeosci. 119, 1919-1933. doi: 10.1002/2014jg002722

Bauch, D., Dmitrenko, I. A., Wegner, C., Hölemann, J., Kirilov, S. A., Timokhov, L. A., et al. (2009). Exchange of Laptev Sea and Arctic Ocean halocline waters in response to atmospheric forcing. J. Geophys. Res. 114, C05008. doi: 10.1029/2008jc005062

Benner, R., Benitez-Nelson, B., Kaiser, K., and Amon, R. M. W. (2004). Export of young terrigenous dissolved organic carbon from rivers to the Arctic Ocean. Geophys. Res. Lett. 31, L05305. doi: 10.1029/2003gl019251

Benner, R., and Opsahl, S. (2001). Molecular indicators of the sources and transformations of dissolved organic matter in the Mississipi river plume. Org. Geochem. 32, 597-611. doi: 10.1016/S0146-6380(00) 00197-2

Boyd, T. J., and Osburn, C. L. (2004). Changes in CDOM fluorescence from allochthonous and autochthonous sources during tidal mixing and bacterial degradation in two coastal estuaries. Mar. Chem. 89, 189-210. doi: 10.1016/j.marchem.2004.02.012

Cauwet, G., and Sidorov, I. S. (1996). The biogeochemistry of Lena river: organic carbon and nutrient distribution. Mar. Chem. 53, 211-227. doi: 10.1016/03044203(95)00090-9

Chari, N. V. H. K., Keerthi, S., Sarma, N. S., Rao Pandi, S., Chiranjeevulu, G., Kiran, R., et al. (2013). Fluorescence and absorption characteristics of dissolved organic matter excreted by phytoplankton species of western Bay of Bengal
K. Bobrov for their assistance during the field sampling. We are thankful to the logistics department of the Alfred Wegener Institute (AWI) particularly Waldemar Schneider for the support, and to Sonja Wiegmann for the work in the laboratory. This work was funded by the Helmholtz Impulse Fond (HGF Young Investigators Group Phytooptics), and by the Presidium of Russian Academy of Sciences program "Prospecting fundamental research in the interest of the Russian Arctic Zone development in 2014-2015" through the project "Biological resources of the Russian Arctic Seas: current state, influence of natural changes and anthropogenic impacts, scientific principles, and perspectives of use." RG is funded by a Ph.D. fellowship from the Coordination for the Improvement of Higher Level Personnel (CAPES-Brazil) in collaboration with the German Academic Exchange Service (DAAD), and a visiting fellowship from the Helmholtz Graduate School for Polar and Marine Research (POLMAR-AWI). CS acknowledges funding from Danish Research Council for Independent Research (DFF 132300336). BH acknowledges grants from the German Science Foundation (DFG 4575) and the Helmholtz Climate Initiative REKLIM.

under axenic laboratory condition. J. Exp. Mar. Biol. Ecol. 445, 148-155. doi: 10.1016/j.jembe.2013.03.015

Coble, P. G. (2007). Marine optical biogeochemistry: the chemistry of ocean color. Chem. Rev. 107, 402-418. doi: 10.1021/cr050350+

Dittmar, T., and Kattner, G. (2003). The biogeochemistry of the river and shelf ecosystem of the Arctic Ocean: a review. Mar. Chem. 83, 103-120. doi: 10.1016/S0304-4203(03)00105-1

Dubinenkov, I., Flerus, R., Schmitt-Kopplin, P., Kattner, G., and Koch, B. P. (2015a). Origin-specific molecular signatures of dissolved organic matter in the Lena Delta. Biogeochemistry 123, 1-14. doi: 10.1007/s10533-014-0049-0

Dubinenkov, I., Kraberg, A., Bussmann, I., Kattner, G., and Koch, B. P. (2015b). Data from: Physical Oceanography and Dissolved Organic Matter in the Coastal Laptev SEA in 2013. PANGAEA. Available online at: http://doi.pangaea.de/10. 1594/PANGAEA.842221

Fedorova, I., Chetverova, A., Bolshiyanov, D., Makarov, A., Boike, J., Heim, B., et al. (2015). Lena Delta hydrology and geochemistry: long-term hydrological data and recent field observations. Biogeosciences 12, 345-363. doi: 10.5194/bg-12345-2015

Fichot, C. G., and Benner, R. (2012). The spectral slope coefficient of chromophoric dissolved organic matter $\left(\mathrm{S}_{275}-295\right)$ as a tracer of terrigenous dissolved organic carbon in river-influenced ocean margins. Limnol. Oceanogr. 57, 1453-1466. doi: 10.4319/lo.2012.57.5.1453

Fichot, C. G., Kaiser, K., Hooker, S. B., Amon, R. M. W., Babin, M., Bélanger, S., et al. (2013). Pan-Arctic distributions of continental runoff in the Arctic Ocean. Sci. Rep. 3:1053. doi: 10.1038/srep01053

Fichot, C. G., and Miller, W. L. (2010). An approach to quantify depth-resolved marine photochemical fluxes using remote sensing: application to carbon monoxide (CO) photoproduction. Remote Sens. Environ. 114, 1363-1377. doi: 10.1016/j.rse.2010.01.019

Fofonova, V., Androsov, A., Danilov, S., Janout, M., Sofina, E., and Wiltshire, K. (2014). Semidiurnal tides in the Laptev Sea Shelf zone in the summer season. Cont. Shelf Res. 73, 119-132. doi: 10.1016/j.csr.2013.11.010

Frey, K. E., and McClelland, J. W. (2009). Impacts of permafrost degradation on arctic river biogeochemistry. Hydrol. Process. 23, 169-182. doi: 10.1002/hyp.7196

Fukuzaki, K., Imai, I., Fukushima, K., Ishii, K.-I., Sawayama, S., and Yoshioka, T. (2014). Fluorescent characteristics of dissolved organic matter produced by bloom-forming coastal phytoplankton. J. Plankton Res. 36, 685-694. doi: 10.1093/plankt/fbu015

Gonçalves-Araujo, R., de Souza, M. S., Tavano, V. M., and Garcia, C. A. E. (2015b) Influence of oceanographic features on spatial and interannual variability of 
phytoplankton in the Bransfield Strait, Antarctica. J. Mar. Syst. 142, 1-15. doi: 10.1016/j.jmarsys.2014.09.007

Gonçalves-Araujo, R., Stedmon, C. A., Heim, B., Dubinenkov, I., Kraberg, A., Moiseev, D., et al. (2015a). Data from: Dissolved Organic Matter in the Lena River Delta Region, Siberia, Russia. PANGAEA. Available online at: http://doi. pangaea.de/10.1594/PANGAEA.844928

Granskog, M., Pavlov, A. K., Sagan, S., Kowalczuk, P., Raczkowska, A., and Stedmon, C. A. (2015). Effect of sea-ice melt on inherent optical properties and vertical distribution of solar radiant heating in Arctic surface waters. J. Geophys. Res. Oceans 120, 7028-7039. doi: 10.1002/2015jc011087

Guéguen, C., Itoh, M., Kikuchi, T., Eert, J., and Williams, W. J. (2015). Variability in dissolved organic matter optical properties in surface waters in the Amerasian Basin. Front. Mar. Sci. 2:78. doi: 10.3389/fmars.2015.00078

Guo, W., Stedmon, C. A., Han, Y., Wu, F., Yu, X., and Hu, M. (2007). The conservative and non-conservative behavior of chromophoric dissolved organic matter in Chinese estuarine waters. Mar. Chem. 107, 357-366. doi: 10.1016/j.marchem.2007.03.006

Heim, B., Abramova, E., Doerffer, R., Günther, F., Hölemann, J., Kraberg, A., et al. (2014). Ocean colour remote sensing in the southern Laptev Sea: evaluation and applications. Biogeosciences 11, 4191-4210. doi: 10.5194/bg-11-4191-2014

Helms, J. R., Mao, J., Stubbins, A., Schmidt-Rohr, K., Spencer, R. G. M., Hernes, P. J., et al. (2014). Loss of optical and molecular indicators of terrigenous dissolved organic matter during long-term photobleaching. Aquat. Sci. 76, 353-373. doi: 10.1007/s00027-014-0340-0

Helms, J. R., Stubbins, A., Ritchie, J. D., Minor, E. C., Kieber, D. J., and Mopper, K. (2008). Absorption spectral slopes and slope ratios as indicators of molecular weight, source, and photobleaching of chromophoric dissolved organic matter. Limnol. Oceanogr. 53, 955-969. doi: 10.4319/lo.2008.53.3.0955

Huguet, A., Vacher, L., Relexans, S., Saubusse, S., Froidefond, J. M., and Parlanti, E. (2009). Properties of fluorescent dissolved organic matter in the Gironde Estuary. Org. Geochem. 40, 706-719. doi: 10.1016/j.orggeochem.2009.03.002

Jørgensen, L., Stedmon, C. A., Kragh, T., Markager, S., Middelboe, M., and Søndergaard, M. (2011). Global trends in the fluorescence characteristics and distribution of marine dissolved organic matter. Mar. Chem. 126, 139-148. doi: 10.1016/j.marchem.2011.05.002

Kara, A. B., Rochford, P. A., and Hurlburt, H. E. (2000a). An optimal definition for ocean mixed layer depth. J. Geophys. Res. 105, 16803-16821. doi: 10.1029/2000JC900072

Kara, A. B., Rochford, P. A., and Hurlburt, H. E. (2000b). Mixed layer depth variability and barrier layer formation over the North Pacific Ocean. J. Geophys. Res. 105, 16783-16801. doi: 10.1029/2000JC900071

Kattner, G., Lobbes, J. M., Fitznar, H. P., Engbrodt, R., Nöthig, E.-M., and Lara, R. J. (1999). Tracing dissolved organic substances and nutrients from the Lena River through Laptev Sea (Arctic). Mar. Chem. 65, 25-39. doi: 10.1016/S03044203(99)00008-0

Kowalczuk, P. M., Durako, J., Young, H., Kahn, A. E., Cooper, W. J., Gonsior, M., et al. (2009). Characterization of dissolved organic matter fluorescence in the South Atlantic Bight with use of PARAFAC model: interannual variability. Mar. Chem. 113, 182-196. doi: 10.1016/j.marchem.2009.01.015

Kowalczuk, P. M., Zabłocka, S., Sagan, and Kuliñski, K. (2010). Fluorescence measured in situ as a proxy of CDOM absorption and DOC concentration in the Baltic Sea. Oceanologia 52, 431-471. doi: 10.5697/oc.52-3.431

Kowalczuk, P., Tilstone, G. H., Zabłocka, M., Röttgers, R., and Thomas, R. (2013). Composition of dissolved organic matter along an Atlantic Meridional transect from fluorescence spectroscopy and parallel factor analysis. Mar. Chem. 157, 170-184. doi: 10.1016/j.marchem.2013.10.004

Levitus, S. (1982). Climatological Atlas of the World Ocean. NOAA Professional Paper 13. Washington, DC: U.S. Govt. Print. Off.

Lyon, S. W., and Destouni, G. (2010). Changes in catchment-scale recession flow properties in response to permafrost thawing in the Yukon River basin. Int. J. Climatol. 30, 2138-2145. doi: 10.1002/joc.1993

McClelland, J. W., Holmes, R. M., Peterson, B. J., and Stieglitz, M. (2004). Increasing river discharge in the Eurasian Arctic: consideration of dams, permafrost thaw, and fires as potential agents of change. J. Geophys. Res. 109, D18102. doi: 10.1029/2004jd004583

McKnight, D. M., Boyer, E. W., Westerhoff, P. K., Doran, P. T., Kulbe, T., and Andersen, D. T. (2001). Spectrofluorometric characterization of dissolved organic matter for indication of precursor organic material and aromaticity. Limnol. Oceanogr. 46, 38-48. doi: 10.4319/lo.2001.46.1.0038

Mopper, K., and Kieber, D. J. (2002). "Photochemistry and the cycling of carbon, sulfer, nitrogen and phosphorus" in Biogeochemistry of Marine Dissolved Organic Matter, eds C. Carlson and D. Hansell (San Diego, CA: Academic Press), 455-508.

Murphy, K. R., Stedmon, C. A., Graeber, D., and Bro, R. (2013). Fluorescence spectroscopy and multi-way techniques. PARAFAC. Anal. Methods 5, 6557-6566. doi: 10.1039/c3ay41160e

Murphy, K. R., Stedmon, C. A., Waite, T. D., and Ruiz, G. M. (2008). Distinguishing between terrestrial and autochthonous organics matter sources in marine environments using fluoresce spectroscopy. Mar. Chem. 108, 40-58. doi: 10.1016/j.marchem.2007.10.003

Murphy, K. R., Stedmon, C. A., Wenig, P., and Bro, R. (2014). OpenFluor an online spectral library for auto-fluorescence by organic compounds in the environment. Anal. Methods 6, 658-661. doi: 10.1039/C3AY41935E

Nelson, N. B., and Siegel, D. A. (2013). The global distribution and dynamics of chromophoric dissolved organic matter. Annu. Rev. Mar. Sci. 5, 447-476. doi: 10.1146/annurev-marine-120710-100751

O’Donnell, J. O., Aiken, G. R., Walvoord, M. A., Raymond, P. A., Butler, K. D., Dornblaser, M. M., et al. (2014). Using dissolved organic matter age and composition to detect permafrost thaw in boreal watersheds of interior Alaska. J. Geophys. Res. Biogeosci. 119, 2155-2170. doi: 10.1002/2014JG002695

Opsahl, S., and Benner, R. (1998). Photochemical reactivity of dissolved lignin in river and ocean waters. Limnol. Oceanogr. 43, 1297-1304. doi: 10.4319/lo.1998.43.6.1297

Opsahl, S., Benner, R., and Amon, R. M. W. (1999). Major flux of terrigenous organic matter through the Arctic Ocean. Limnol. Oceonogr. 44, 2017-2023. doi: 10.4319/lo.1999.44.8.2017

Para, J., Coble, P. G., Charrière, B., Tedetti, M., Fontana, C., and Sempéré, R. (2010). Fluorescence and absorption properties of chromophoric dissolved organic matter (CDOM) in coastal surface waters of the northwestern Meditteranean Sea, influence of the Rhône River. Biogeosciences 7, 4083-4103. doi: 10.5194/bg-7-4083-2010

Peterson, B. J., Holmes, R. M., McClelland, J. W., Vörösmarty, C. J., Lammers, R. B., Shiklomanov, I. A., et al. (2002). Increasing river discharge to the Arctic Ocean. Science 298, 2171-2173. doi: 10.1126/science.1077445

Porcal, P., Dillon, P. J., and Molot, L. A. (2013). Photochemical production and decomposition of particulate organic carbon in a freshwater stream. Aquat. Sci. 73, 469-482. doi: 10.1007/s00027-013-0293-8

Porcal, P., Dillon, P. J., and Molot, L. A. (2015). Temperature dependence of photodegradation of dissolved organic matter to dissolved inorganic carbon and particulate organic carbon. PLOS ONE 10:e0128884. doi: 10.1371/journal.pone.0128884

Raymond, P. A., McClelland, J. W., Holmes, R. M., Zhulidov, A. V., Mull, K., Peterson, B. J., et al. (2007). Flux and age of dissolved organic carbon exported to the Arctic Ocean: a carbon isotopic study of the five largest arctic rivers. Global Biogeochem. Cycles 21, GB4011. doi: 10.1029/2007 GB002934

Romera-Castillo, C., Sarmento, H., Álvarez-Salgado, X. A., Gasol, J. M., and Marrasé, C. (2010). Production of chromophoric dissolved organic matter by marine phytoplankton. Limnol. Oceanogr. 55, 446-454. doi: 10.4319/lo.2010.55.1.0446

Sánchez-García, L., Vonk, J. E., Charkin, A., Kosmach, D., Dudarev, O., Semiletov, I., et al. (2014). Characterisation of three regimes of collapsing Arctic ice complex deposits on the SE Laptev Sea coast using biomarkers and dual carbon isotopes. Permafrost Periglacial Process. 25, 172-183. doi: 10.1002/ppp.1815

Schlitzer, R. (2015). Ocean Data View. Available online at: http://odv.awi.de

Schuur, E. A. G., Bockheim, J., Canadell, J. G., Euskirchen, E., Field, C. B., Goryachkin, S. V., et al. (2008). Vulnerability of permafrost carbon to climate change: implications for the global carbon cycle. Bioscience 58, 701-714. doi: 10.1641/B580807

Semiletov, I. P., Pipko, I. I., Shakhova, N. E., Dudarev, O. V., Pugach, S. P., Charkin, A. N., et al. (2011). Carbon transport by the Lena River from its headwaters to the Arctic Ocean, with emphasis on fluvial input of terrestrial particulate organic carbon vs. carbon transport by coastal erosion. Biogeosciences 8, 2407-2426. doi: 10.5194/bg-8-2407-2011 
Semiletov, I. P., Shakhova, N. E., Pugach, S. P., Charkin, A. N., Dudarev, O. V., Kosmach, D. A., et al. (2013). Space-time dynamics of carbon and environmental parameters related to carbon dioxide emissions in the BuorKhaya Bay and adjacent part of the Laptev Sea. Biogeosciences 10, 5977-5996. doi: 10.5194/bg-10-5977-2013

Semiletov, I. P., Shakhova, N. E., Sergienko, V. I., Pipko, I. I., and Dudarev, O. V. (2012). On carbon transport and fate in the East Siberian Arctic landshelf-atmosphere system. Environ. Res. Lett. 7, 015201. doi: 10.1088/1748$9326 / 7 / 1 / 015201$

Senesi, N., Miano, N. T., Provenzano, M. R., and Brunetti, G. (1991). Characterization, differentiation and classification of humic substances by fluorescence spectroscopy. Soil Sci. 152, 259-271. doi: 10.1097/00010694199110000-00004

Shank, G. C., Zepp, R. G., Whitehead, R. F., and Moran, M. A. (2005). Variations in the spectral properties of freshwater and estuarine CDOM caused by partitioning onto river and estuarine sediments. Estuar. Coast. Shelf Sci. 65, 289-301. doi: 10.1016/j.ecss.2005.06.009

Siegel, D. A., Maritorena, S., Nelson, N. B., Behrenfeld, M. J., and McClain, R. (2005). Colored dissolved organic matter and its influence on the satellite-based characterization of the ocean biosphere. Geophys. Res. Lett. 32, L20605. doi: $10.1029 / 2005 \mathrm{~g} 1024310$

Siegel, D. A., Maritorena, S., Nelson, N. B., Hansell, D. A., and LorenziKayser, M. (2002). Global distribution and dynamics of colored dissolved and detrital organic materials. J. Geophys. Res. 107, 3228. doi: 10.1029/2001jc0 00965

Singh, S., D'Sa, E. J., and Sweson, E. M. (2010). Chromophoric dissolved organic matter $(\mathrm{CDOM})$ variability in Barataria Basin using excitation-emission matrix (EEM) fluorescence and parallel factor analysis (PARAFAC). Sci. Total Environ. 408, 3211-3222. doi: 10.1016/j.scitotenv.2010.03.044

Spencer, R. G. M., Aiken, G. R., Butler, K. D., Dornblaser, M. M., Striegl, R. G., and Hernes, P. J. (2009). Utilizing chromophoric dissolved organic matter measurements to derive export and reactivity of dissolved organic carbon exported to the Arctic Ocean: a case study of the Yukon River, Alaska. Geophys. Res. Lett. 36, L06401. doi: 10.1029/2008gl036831

Stedmon, C. A., Amon, R. M. W., Rinehart, A. J., and Walker, S. A. (2011). The supply and characteristics of colored dissolved organic matter (CDOM) in the Arctic Ocean: par Arctic trends and differences. Mar. Chem. 124, 108-118. doi: 10.1016/j.marchem.2010.12.007

Stedmon, C. A., and Bro, R. (2008). Characterizing dissolved organic matter fluorescence with parallel factor analysis: a tutorial. Limnol. Oceanogr. 6, 572-579. doi: 10.4319/lom.2008.6.572

Stedmon, C. A., and Markager, S. (2003). Behaviour of the optical properties of coloured dissolved organic matter under conservative mixing. Est. Cost. Shelf Sci. 57, 1-7. doi: 10.1016/s0272-7714(03)00003-9

Stedmon, C. A., and Markager, S. (2005). Resolving the variability in dissolved organic matter fluorescence in a temperate estuary and its catchment using PARAFAC analysis. Limnol. Oceanogr. 50, 686-697. doi: 10.4319/lo.2005.50.2.0686

Stevenson, F. J. (1982). Humus Chemistry. New York, NY: Genesis, Composition, Reactions, Willey-Interscience.

Stubbins, A., Lapierre, J.-F., Berggren, M., Prairia, Y. T., Dittmar, T., and del Giorgio, P. A. (2014). What's in an EEM? Molecular signatures associated with dissolved organic fluorescence in boreal Canada. Environ. Sci. Technol. 48, 10598-10606. doi: 10.1021/es502086e

Stubbins, A., Uher, G., Law, C. S., Mopper, K., Robinson, C., and Upstill-Goddard, R. C. (2006). Open-ocean carbon monoxide photoproduction. Deep Sea Res. II 53, 1695-1705. doi: 10.1016/j.dsr2.2006.05.011

Timko, S. A., Maydanov, A., Pittelli, S. L., Conte, M. H., Cooper, W. J., Koch, B. P., et al. (2015). Depth-dependent photodegradation of marine dissolved organic matter. Front. Mar. Sci. 2:66. doi: 10.3389/fmars.2015.00066

Uher, G., Hughes, C., Henry, G., and Upstill-Goddard, R. C. (2001). Nonconservative mixing behavior of colored dissolved organic matter in a humic-rich, turbid estuary. Geophys. Res. Lett. 28, 3309-3312. doi: 10.1029/2000GL012509

von Wachenfeldt, E., Sobek, S., Batsviken, D., and Tranvik, L. J. (2008). Linking allochthonous dissolved organic matter and boreal lake sediment carbon sequestration: the role of light-mediated flocculation. Limnol. Oceanogr. 53, 2416-2426. doi: 10.4319/lo.2008.53.6.2416
Vonk, J. E., Sánchez-García, L., van Dongen, B. E., Alling, V., Kosmach, D., Charkin, A., et al. (2012). Activation of old carbon by erosion of coastal and subsea permafrost in Arctic Siberia. Nature 489, 137-140. doi: 10.1038/nature11392

Vonk, J. E., Semiletov, I., Dudarev, O., Eglinton, T., Andersson, A., Shakhova, N., et al. (2014). Preferential burial of permafrost-derived organic carbon in Siberian-Arctic shelf waters. J. Geophys. Res. 119, 8410-8421. doi: 10.1002/2014JC010261

Walker, S. A., Amon, R. M. W., and Stedmon, C. A. (2013). Variations in high-latitude riverine fluorescent dissolved organic matter: a comparison of large Arctic rivers. J. Geophys. Res. Biogeosci. 118, 1689-1702. doi: 10.1002/2013jg002320

Walker, S. A., Amon, R. M. W., Stedmon, C., Duan, S., and Louchouarn, P. (2009). The use of PARAFAC modeling to trace terrestrial dissolved organic matter and fingerprint water masses in coastal Canadian Arctic surface waters. J. Geophys. Res. 114, G00F06. doi: 10.1029/2009jg000990

Wegner, C., Bauch, D., Hölemann, J. A., Janout, M. A., Heim, B., Novikhin, A., et al. (2013). Interannual variability of surface and bottom sedminet transport on Laptev Sea shelf during summer. Biogeosciences 10, 1117-1129. doi: 10.5194/bg10-1117-2013

Weishaar, J. L., Aiken, G. R., Bergamaschi, B. A., Fram, M. S., Fujii, R., and Mopper, K. (2003). Evaluation of specific ultraviolet absorbance as an indicator of the chemical composition and reactivity of dissolved organic carbon. Environ. Sci. Technol. 37, 4702-4708. doi: 10.1021/es030360x

Yamashita, Y., Boyer, J. N., and Jaffé, R. (2013). Evaluating the distribution of terrestrial dissolved organic matter in a complex coastal ecosystem using fluorescence spectroscopy. Cont. Shelf Res. 66, 136-144. doi: 10.1016/j.csr.2013.06.010

Yamashita, Y., Cory, R. M., Nishioka, J., Kuma, K., Tanoue, E., and Jaffé, R. (2010). Fluorescence characteristics of dissolved organic matter in the deep waters of the Okhotsk Sea and the northwestern North Pacific Ocean. Deep Sea Res. II 57, 1478-1485. doi: 10.1016/j.dsr2.2010.02.016

Yamashita, Y., Fichot, C. G., Shen, Y., Jaffé, R., and Benner, R. (2015). Linkages among fluorescent dissolved organic matter, dissolved amino acids and ligninderived phenols in a river-influenced ocean margin. Front. Mar. Sci. 2:92. doi: 10.3389/fmars.2015.00092

Yamashita, Y., and Tanoue, E. (2003). Chemical characterization of protein-like fluorophores in DOM in relation to aromatic amino acids. Mar. Chem. 82, 255-271. doi: 10.1016/S0304-4203(03) 00073-2

Yamashita, Y., and Tanoue, E. (2004). Chemical characteristics of amino acidcontaining dissolved organic matter in seawater. Org. Chem. 35, 679-692. doi: 10.1016/j.orggeochem.2004.02.007

Yang, D., Kane, D. L., Hinzman, L. D., Zhang, X., Zhang, T., and Ye, H. (2002). Siberia Lena River hydrologic regime and recent change. J. Geophys. Res. 107, 4694. doi: 10.1029/2002JD002542

Zhang, Y., van Dijk, M. A., Liu, M., Zhu, G., and Qin, B. (2009). The contribution of phytoplankton degradation to chromophoric dissolved organic matter (CDOM) in eutrophic shallow lakes: field and experimental evidence. Water Res. 43, 4685-4697. doi: 10.1016/j.watres.2009.07.024

Zsolnay, Á., Baigar, E., Jimenez, E., Steinweg, B., and Saccomandi, F. (1999). Differentiating with fluorescence spectroscopy the source of dissolved organic matter in soils subjected to drying. Chemosphere 38, 45-50. doi: 10.1016/S00456535(98)00166-0

Zsolnay, Á. (2003). Dissolved organic matter: artefacts, definitions and functions. Geoderma 113, 187-209. doi: 10.1016/S0016-7061(02)00361-0

Conflict of Interest Statement: The authors declare that the research was conducted in the absence of any commercial or financial relationships that could be construed as a potential conflict of interest.

Copyright () 2015 Gonçalves-Araujo, Stedmon, Heim, Dubinenkov, Kraberg, Moiseev and Bracher. This is an open-access article distributed under the terms of the Creative Commons Attribution License (CC BY). The use, distribution or reproduction in other forums is permitted, provided the original author $(s)$ or licensor are credited and that the original publication in this journal is cited, in accordance with accepted academic practice. No use, distribution or reproduction is permitted which does not comply with these terms. 